Fall 1987

\title{
Do the DOJ Vertical Restraints Guidelines Provide Guidance?
}

\author{
Alan A. Fisher Ph.D. \\ Bureau of Economics, Federal Trade Commission \\ Frederick I. Johnson \\ Bureau of Economics, Federal Trade Commission \\ Robert H. Lande \\ University of Baltimore School of Law, rlande@ubalt.edu
}

Follow this and additional works at: http://scholarworks.law.ubalt.edu/all_fac
Part of the Antitrust and Trade Regulation Commons, Consumer Protection Law Commons, and the Law and Economics Commons

\section{Recommended Citation}

Do the DOJ Vertical Restraints Guidelines Provide Guidance?, 32 Antitrust Bull. 609 (1987) 


\section{Do the DOJ Vertical Restraints Guidelines provide guidance?}

BY ALAN A. FISHER,* FREDERICK I. JOHNSON,* and ROBERT H. LANDE**

\section{The historical perspective}

Vertical restraints come in a glittering menu of exceptional variety, including resale price maintenance (RPM), tying, exclusive dealing, requirements contracts, "best efforts" clauses, full-line forcing, airtight and nonairtight exclusive territories, customer restrictions, areas of primary responsibility, profit-passover pro-

- Bureau of Economics, Federal Trade Commission, Washington, D.C. 20580.

** University of Baltimore School of Law.

AUTHORS' NOTE: The opinions in this article are solely those of the authors and do not necessarily express the views of our colleagues, the Bureau of Economics, the Commission, or any individual commissioner.

The authors presented an earlier version of this article at a Contemporary Policy Session at the Western Economic Association Conference in Anaheim, California. We thank James Langenfeld, Howard Marvel, Thomas Overstreet, Steven Ross, Joe Sims, and Robert Steiner for many useful comments on earlier drafts of this article. We also thank the late Joseph Fortenberry for many useful comments and suggestions of case citations to illustrate points in this article.

¿ 1987 by Federal Legal Publications, Inc. 
visions, restrictions on locations of outlets, and dual distribution. ${ }^{1}$ Firms sometimes combine vertical restraints into packages. The great variety of individual and combined vertical restraints complicates the discovery of market effects. Indeed, identifying what restraint(s) a given firm is using at any particular time can be difficult. ${ }^{2}$

Despite the multiplicity of vertical restraints, both economics and the law have focused on them singly rather than in combinations. Most cases and theoretical and policy discussions have examined RPM separately from "airtight" non-price vertical restraints (exclusive dealing, exclusive territories, and tying), the vertical restraints typically considered most likely to affect resource allocation and consumers, rather than analyzing combinations of restraints. ${ }^{3}$

1 Vertical integration and acquisition of a (or several) vertically related firm(s) are alternative forms of vertical control and can often achieve the same results, except for any differences in transaction costs. For a thorough analysis, including definitions, see P. AreedA, ANTITrust Analysis: Problems, Text, Cases 11 500-74 (3d ed. 1981).

2 For example, it is often difficult to distinguish exclusive dealing, full-line forcing, and tying (id. II 558-63; Pittman, Tying Without Exclusive Dealing, 30 AnTITRUST Bull. 279 (1985); Jefferson Parish Hospital District No. 2 v. Hyde, 104 S. Ct. 1551 (1984); Federal Trade Commission v. Sinclair Co., 261 U.S. 463 (1923)), or to differentiate RPM from non-price vertical restraints (World of Sleep, Inc. v. La-ZBoy Chair Co., 756 F.2d 1467 (10th Cir. 1985); Lewis Service Center, Inc. v. Mack Trucks, Inc., 714 F.2d 842 (8th Cir. 1983), cert. denied, 104 U.S. 2678 (1984); AAA Liquors, Inc. v. Joseph E. Seagram \& Sons, 705 F.2d 1203 (10th Cir. 1982), cert. denied, 103 S. Ct. 1903 (1983); Eastern Scientific Co. v. Wild Heerbrugg Instruments, Inc., 572 F.2d 883 (1st Cir.), cert. denied, 439 U.S. 833 (1978); In re Nissan Antitrust Litigation, 577 F.2d 910 (5th Cir. 1978)), or unilateral manufacturer behavior (Monsanto Co. v. Spray-Rite Service Corp., 104 S. Ct. 1464 (1984); Russell Stover Candies, Inc. v. Federal Trade Commission, 718 F.2d 256 (1983); Yentsch v. Texaco, Inc., 630 F.2d 46 (2d Cir. 1980); Arnott v. American Oil Co., 609 F.2d 873 (8th Cir. 1979), cert. denied, 446 U.S. $918(1980))$.

3 In effect, analysts have been studying checkers because chess is too difficult. However, business necessity forces the private bar to puzzle over the more complex questions. See, e.g., M. Denger \& W. Tom, 
RPM has generally been per se illegal, except per se legal until 1975 in fair-trade states; ${ }^{4}$ tying was per se illegal under certain circumstances; ${ }^{5}$ exclusive dealing was subject to a rule of reason analysis; ${ }^{6}$ and territorial and customer restrictions were generally

Relationships With Suppliers, Customers and Franchisees (May 29-30, 1986) (unpublished notes for Practising Law Institute, 27th Annual Antitrust Law Institute); M. Denger \& R. Joseph, Hypothetical Problems (May 7, 1985) (unpublished material for International Franchising Association, 18th Annual Legal Symposium, Workshop on Vertical Price and Nonprice Restrictions). We thank Michael Denger for making these insightful materials available to us.

4 For details, see Overstreet \& Fisher, Resale Price Maintenance and Distributional Efficiency: Some Lessons From the Past, 3 CONTEMP. Pol'y Issues 43, 44-45 (1985). The courts have determined some practices to be essentially devoid of any redeeming value and thus "per se" or automatically illegal. For such practices, courts will condemn a practice without requiring an examination of the user's market power or of the actual effects of the practice. For practices where significant socially desirable effects are plausible enough, courts require a detailed examination of actual effects-i.e., rule of reason. In practice, however, this distinction is often unclear. See, e.g., Areeda, The Changing Contours of the Per Se Rule, 54 ANTITRUST L.J. 27 (1985). Further, the Court may be moving away from using a per se standard in many situations where it has done so in the past. See, e.g., Gellhorn \& Tatham, Making Sense Out of the Rule of Reason, 35 CASE W. RES. L. REv. 155 (1984-85); Northwest Wholesale Stationers, Inc. v. Pacific Stationery \& Printing Co., 105 S. Ct. 2613 (1985); National Collegiate Athletic Ass'n v. Board of Regents of University of Oklahoma, 104 S. Ct. 2948 (1984); Broadcast Music v. Columbia Broadcasting System, 441 U.S. 1 (1979).

5 Illegal tying generally requires a demonstration that there are two distinct products and that a firm with monopoly power in the tying product affects a "quantitatively substantial" amount of the tied product's market. In essence, then, one must perform a rule of reason analysis to apply the so-called per se test. For a recent discussion, see Sims \& Lande, Vertical Restraints Guidelines: A Step Forward, Legal Times, Mar. 4, 1985, at 16.

6 Although the Court did not understand how RPM or tying could yield any efficiencies, since Standard Oil Co. v. United States (Standard Stations), 337 U.S. 293 (1949), it has recognized the possibility of efficiencies from exclusive dealing. See D. Pegrum, Public Regulation of BUSINESS 403-08 (1965), for the early development of the legal status of exclusive dealing. The concurring opinions in Continental T.V., Inc. v. 
legal. ${ }^{7}$ In 1948, the Department of Justice (DOJ) announced its policy of treating virtually all intrabrand non-price vertical restraints as per se illegal. ${ }^{8}$ In 1967, the Supreme Court adopted the Department's view, at least for restrictions on customers or locations. ${ }^{9}$ In 1975, Congress repealed the fair-trade legislation and returned RPM to its status of per se illegal. ${ }^{10}$

GTE Sylvania, Inc., 433 U.S. 36 (1977), and Jefferson Parish Hospital District No. 2 v. Hyde, 104 S. Ct. 1551 (1984), did recognize efficiencies from RPM and from tying. J. Fortenberry, A History of the Antitrust Law of Vertical Practices 96, n.264 (1985) (unpublished manuscript forthcoming in 11 RESEARCH IN LAW \& ECONOMICS), considers the Standard Stations rule a modified per se standard.

7 The government did not challenge territorial and other similar restrictions, and the courts typically found such restraints legal under a rule of reason analysis in private cases. See A.B.A. AntrTrust Section, VerTiCal Restraints Limiting INTRABRAND COMPETITION 6-7 (1977) [hereinafter cited as A.B.A.].

$8 \quad I d$.

9 These restrictions include exclusive territories, locational restrictions (specifying where a distributor may and where it may not sell the product in question), areas of primary responsibility, and profitpassover arrangements (where a distributor must compensate a dealer if it sells to customers located in other dealers' areas of primary responsibility). Id. at 3-4.

In United States v. Bausch \& Lomb Optical Co., 321 U.S. 707 (1944), the Court found non-price vertical territorial restrictions per se illegal if they were an integral part of an RPM agreement. Based on this ruling, the Justice Department argued that "airtight" territorial and customer restrictions were per se illegal. The first litigated case to challenge this view was White Motor Co. v. United States, 372 U.S. 253 (1963), where the Court ordered an examination of actual effects (essentially a rule of reason analysis). The Court finally accepted the arguments for per se illegality for at least some non-price vertical restraints in United States v. Arnold, Schwinn \& Co., 388 U.S. 365 (1967).

By the late 1960 s, one might have feared for the legality of all nonprice vertical restraints. Lower courts, however, frequently ignored Schwinn and invented numerous evasions to uphold non-price vertical restrictions. However, the courts continued to uphold most instances of exclusive dealing. For a thorough discussion, see A.B.A., supra note 7, at 6-25.

10. Overstreet \& Fisher, supra note 4 , at $44-45$. 
Since 1975, the legal status of vertical restraints has changed. For restrictions on customers and locations, the uproar of criticism over Schwinn induced the Court to reverse itself less than a decade later and make all non-price vertical restraints except tying subject to a rule of reason analysis." In recent years, courts have upheld virtually all uses of non-price vertical restraints, including tying, except for manufacturers with large market shares. ${ }^{12}$ Indeed, the Supreme Court has not found any non-price vertical restraints illegal (on vertical grounds) for more than 20 years, except in cases that it later overruled. It has also denied certiorari in many cases that would have offered an opportunity to reaffirm the illegality of non-price vertical restraints under earlier case law. In contrast, the Court has reaffirmed its per se standard for RPM on many occasions. However, it has increased the legal burden for finding RPM and tying illegal under the per se standard. ${ }^{13}$

The changing legal status of vertical restraints largely followed reinterpretations among economists and legal commentators. During the 1960 s, industrial organization texts generally summarized the arguments against vertical restraints and rele-

11 Continental T.V., Inc. v. GTE Sylvania, Inc., 433 U.S. 36 (1977).

12 J. Rill, Territorial and Customer Restraints (1985) (unpublished paper).

13 The Court increased the evidentiary burden for finding illegal RPM in Monsanto Co. v. Spray-Rite Service Corp., 104 S. Ct. 1464 (1984), and tying in Jefferson Parish Hospital District No. 2 v. Hyde, 104 S. Ct. 1551 (1984). The Supreme Court has not found a non-price vertical restraints package illegal since United States v. Topco Assocs., 405 U.S. 596 (1972). However, Topco does not really count, because the Court considered it a horizontal cartel among dealers rather than a vertical restraint between the manufacturer and dealers. See also infra note 45. Prior to Topco, the Court had found illegal tying in Fortner Enterprises v. United States Steel Corp. (Fortner I), 394 U.S. 495 (1969), which it reversed in United States Steel Corp. v. Fortner Enterprises (Fortner II), 429 U.S. 610 (1977), after a new trial. Prior to Fortner I, the most recent Supreme Court case to find non-price vertical restraints illegal was United States v. Arnold, Schwinn \& Co., 388 U.S. 365 (1967), which the Court explicitly overruled in Continental T.V., Inc. v. GTE Sylvania, Inc., 433 U.S. 36 (1977). 
gated counterarguments and skeptics to footnotes. ${ }^{14}$ By the late 1970s, however, most economists had accepted the theoretical proposition that vertical restraints often permit important efficiencies and cannot increase overall market power or allow firms otherwise to extend their market power, except under specialized conditions. ${ }^{\text {is }}$

The 1985 Department of Justice Vertical Restraints Guidelines $^{16}$ reflect the dominant current economic analysis and go beyond current case law in an attempt to induce courts to continue the trend toward a more permissive policy toward nonprice vertical restraints. ${ }^{17} \mathrm{~A}$ combination of objective rules and

14 See, e.g., F. Scherer, Industrial Market Structure and EcoNomic Performance 505-16 (1970); J. Bain, Industrial Organization 357-64, 658-60 (1968); D. PEGRUM, supra note 6, at 391-409.

15 Compare F. Scherer, Industrial Market Structure and EcoNomic Performance 582-94 (2d ed. 1980), with F. Scherer, supra note 14, at 505-16; see also R. BlaIR \& D. KasERMAN, LaW AND ECONOMICS OF Vertical Integration and Control (1983); R. Bork, The Antitrust Paradox 280-301 (1978); F. Warren-Boulton, Vertical Control of Markets (1978); R. Posner, Antitrust law: An Economic Perspective 171-84, 196-207 (1976).

16 U.S. Dep't of Justice, Vertical Distribution Restraints Guidelines, 50 Fed. Reg. 6263 (1985) [hereinafter cited as Vertical Guidelines]. Although the Federal Trade Commission did not sign the guidelines, the Commission seems likely to follow its reaction to the 1982 Merger Guidelines and give the Vertical Restraints Guidelines "substantial weight" in its analysis of vertical restraints cases. Indeed, then-Bureau of Competition Director Timothy J. Muris praised the analysis in the guidelines. See BNA, Vertical Restraints Guidelines Evoke Mixed Reception Within Antitrust Bar, 48 Antitrust \& Trade Reg. Rer. 237 (Jan. $31,1985)$.

17 Sims \& Lande, supra note 5; A. Abbott, The Justice Department's Vertical Restraints Guidelines (1985) (unpublished paper presented to the New York Law Journal's Sixth Annual Program on Distribution, New York, Apr. 19, 1985); Vertical Guidelines, supra note $16, \S 1$. Indeed, former Assistant Attorney General for Antitrust Thomas E. Kauper described the guidelines as "more in the nature of an amicus brief, designed primarily to influence courts in private cases to which the Division is not a party . . . a revelation of what the Antitrust Division believes the law should be." See BNA, Monopolies Subcommit- 
wide-open discretion, the guidelines designate a large structural safe zone for non-price vertical restraints. However, for instances that exceed the structural thresholds, the guidelines provide only a general indication that challenges will be rare, without indicating the precise circumstances under which the government would actually intervene.

\section{The economics of vertical restraints}

\section{A. Increasing appreciation of efficiency potential}

In reaction to the government's strict treatment of vertical restraints after World War II and the cursory treatment in economic textbooks, a few skeptics, primarily associated physically or ideologically with the University of Chicago, started to question their presumed anticompetitive potential during the 1950s and 1960s. ${ }^{18}$ Wouldn't manufacturers typically tend to have more market power than retailers or distributors, exploit this power by raising the wholesale price, and keep their distributors' and retailers' margins as low as possible? If so, why would manufacturers impose vertical restraints whose primary effect would seemingly be to shift some of their profits to their dealers? This analysis suggested that manufacturers might voluntarily adopt vertical restraints to correct a market failure or

tee Receives Views on Division's Enforcement Track Record, 48 ANTITRUST \& TRADE REG. Rer. 455, 456 (Mar. 14, 1985). For a similar evaluation, see House Judiciary Committee, Resale Price Maintenance Portion of House Judiciary Committee's Report on H.R. 2348 to Authorize Appropriations for Justice Department for Fiscal 1986, reprinted in 48 Antitrust \& Trade Reg. Rep. (BNA) 1025 (June 13, 1985).

18 See, e.g., Bork, The Rule of Reason and the Per Se Concept: Price Fixing and Market Division II, 75 YALE L.J. 373-475 (1966); Bork, The Rule of Reason and the Per Se Concept: Price Fixing and Market Division I, 74 YALE L.J. 775 (1965); Burstein, $A$ Theory of Full-Line Forcing, 55 Nw. U.L. Rev. 62 (1960); Telser, Why Should Manufacturers Want Fair Trade?, 3 J.L. \& Econ. 86 (1960); Bowman, The Prerequisites and Effects of Resale Price Maintenance, 22 U. CHI. L. Rev. 825 (1955); B. Yamey, The Economics of Resale Price Maintenance (1954). 
otherwise to enhance efficiency. The analysis led to explanations of how vertical control could reduce transaction costs, eliminate costly duplication and permit economies of scale in distribution, facilitate entry, eliminate all sorts of free-rider effects, and protect the quality and reputation of a manufacturer's brand. ${ }^{19} \mathrm{Al}-$ though as yet there is only modest empirical evidence of the magnitude of these effects, ${ }^{20}$ the theoretical basis for their frequent presence seems compelling.

\section{B. Can vertical restraints have anticompetitive effects?}

The anticompetitive analysis of vertical restraints is more complex and controversial and therefore requires a more detailed discussion. ${ }^{21}$ Vertical restraints might increase overall market power in four ways: they might increase market power at a single stage, increase entry barriers, facilitate collusion, or raise rivals' costs. ${ }^{22}$ Vertical restraints might also enhance retailers' product differentiation activities and thereby have complex effects on competition and consumers' welfare.

19 See, e.g., Marvel \& McCafferty, Resale Price Maintenance and Quality Certification, 15 RAND J. ECON. 346 (1984); Klein, Crawford \& Alchian, Vertical Integration, Appropriable Rents, and the Competitive Contracting Process, 21 J.L. \& Econ. 297 (1978); O. Wil.liamson, MaRKETS AND HIERARCHIES: ANALYSIS AND ANTITRUST IMPLICATIONS (1975); for a summary, see Fisher \& Sciacca, An Economic Analysis of Vertical Merger Enforcement Policy, in 6 REs. L. \& ECON. 1, 12-16 (R. Zerbe ed. 1984).

20 For discussions of these studies, see R. LAFFERTY, R. LANDE \& J. Kirkwood, Impact Evaluations of Federal Trade Commission Vertical Restraints Cases (1984); T. Overstreet, Resale Price Maintenance: Economic Theories and Empirical Evidence (Federal Trade Commission Staff Report 1983).

21 The comparative length of this section carries no implication for the frequency of anticompetitive effects in comparison to efficiencies from vertical restraints.

22 For a more thorough discussion in the often analogous context of vertical mergers, see Fisher \& Sciacca, supra note 19, at 16-33. 
1. INCREASING MARKET POWER AT A SINGLE STAGE Many economists argue on theoretical grounds that vertical restraints cannot increase market power at a single stage. Consider the simple dichotomy of competition and monopoly. If both vertically related stages are initially competitive, their vertical combination cannot create market power anew. ${ }^{23}$ If both stages are already monopolized, their vertical combination cannot increase overall monopoly power. ${ }^{24}$ If a firm already monopolizes a "downstream" market (the stage closer to ultimate users), market control at the earlier stage would add nothing to its ability to raise prices. Rather, the monopolist would want its suppliers to be as competitive as possible; market power "upstream" would therefore detract from the downstream monopolist's position.

With the simple competition-monopoly dichotomy, then, the only interesting case is apparently when a monopolist uses vertical control to acquire market power downstream. An economist who views distribution or retailing as inherently competitive naturally poses the question in these terms. ${ }^{25}$

This reasoning offers no potential for vertical restraints to harm competition. However, oligopoly complicates the analysis.

23 See, e.g., F. WARREn-Boulton, supra note 15.

24 Indeed, such a combination would eliminate the distortion of double monopoly and thereby be procompetitive. Machlup \& Taber, Theories of the Firm: Marginalist, Behavioral, Managerial, 57 Ам. ECON. Rev. 1 (1967).

25 As Bork characterized this literature, "There is a faint theoretical case, hardly worth mentioning [of an anticompetitive effect], . . . but it is doubtful that narrow possibility has any application to reality." $R$. BoRk, supra note 15 , at 226 . Bork was characterizing the theoretically equivalent situation of vertical merger. The "faint theoretical case" is where user firms can easily substitute other inputs for some of their requirements of the monopolized product. For a summary and citations, see Fisher \& Sciacca, supra note 19, at 18-21. Even in the "faint theoretical case," efficiencies from vertical control could offset any anticompetitive effects. This line of analysis has brought the economics profession to a general agreement that vertical restraints should normally be legal. 
Salinger ${ }^{26}$ and Perry ${ }^{27}$ have developed oligopoly models in which vertical control may lead to higher prices. Also, the analysis is fragmentary and offers no general conclusions about the effects of vertical control in oligopoly. These models analyze only the direct effects of vertical restraints. However, if vertical control leads firms to change their views of how they (and their competitors) will react to changes in output (what economists call "conjectural variations"), then the range of anticompetitive possibilities becomes far richer. ${ }^{28}$

2. RAISING ENTRY BARRIERS Many commentators have alleged that vertical restraints-especially restricted distributioncan raise entry barriers. ${ }^{29}$ Intuitively, existing firms tie up all existing distributors or retailers with exclusive dealing arrangements so that entrants must find or create new distributors or retailers or induce existing ones to switch. Many economists have been skeptical of these allegations. ${ }^{30}$ Suppose, for example, that existing manufacturers have exclusive contracts with the best (most efficient) retailers. The allegation that vertical restraints raise entry barriers is essentially that it is harder (i.e., requires greater retailer margins) for a new entrant to induce retailers to switch suppliers than it was for the original entrants to

26 M. Salinger, Vertical Mergers and Market Foreclosure With Differentiated Products (1986) (unpublished paper, Columbia U.).

27 M. Perry, The Theory of Vertical Integration by Imperfectly Competitive Firms (Ph.D. diss., Stanford U. 1976).

28 See infra Section II.B.3. For a more detailed discussion, see A. Fisher, F. Johnson \& R. Lande, Mergers, Market Power, and Property Rights: When Will Efficiencies Prevent Price Increases? (Federal Trade Commission, Bureau of Economics Working Paper No. 130, 1985).

29 Indeed, the Vertical Guidelines, supra note 16, feature this possibility prominently in $\S 3.22$. See also Krattenmaker \& Salop, Anticompetitive Exclusion: Raising Rivals' Costs to Achieve Power Over Price, 96 YALE L.J. 209 (1986).

30 For a thorough discussion, see Fisher \& Sciacca, supra note 19, at 22-27. 
induce them to carry the product line. ${ }^{31}$ Alternatively, new entrants might have to create their own distribution or sales organizations if existing channels were tied into existing manufacturers. This scenario essentially alleges capital market barriers or management bottlenecks. ${ }^{32}$ A special problem might arise if an entrant's expected market share would be too small to support exclusive distributors or retailers and dual distributors or retailers were unavailable (because of exclusive contracts) or less efficient than exclusives. ${ }^{33}$ These allegations have been common in soft drinks and automobiles. ${ }^{34}$ However, if ex-

31 This formulation of entry barriers follows Stigler's definition. For a discussion of alternative definitions of entry barriers, see Demsetz, Barriers to Entry, 72 Am. Econ. Rev. 47 (1982). The U.S. Department of Justice Merger Guidelines, 49 Fed. Reg. 26,824 (1984) [hereinafter cited as Merger Guidelines], define entry barriers in terms of the amount of time that entry is delayed. Under this definition, vertical restraints are more likely to raise entry barriers.

First-entrant theories enjoyed some popularity a few years ago. See, e.g., I. Whitten, Brand Performance in the Cigarette Industry and THE ADVANTAGE TO EARLY ENTRY, 1913-74 (FTC Economic Report 1979); R. Bond \& D. Lean, Sales, Promotion, and Product Differentiation in Two Prescription Drug Markets (FTC Staff Report 1977). However, there is minimal evidence that first entrants generally have lower costs than subsequent entrants of obtaining brand loyalties.

32 On capital market barriers, see the discussion by Fisher \& Sciacca, supra note 19 , at 25-26. There is insufficient evidence to assess the empirical importance of vertical restraints in creating capital market entry barriers. The management bottleneck hypothesis is that managers of a manufacturing firm cannot manage distributing or retailing as well as they can coordinate activities with independent firms that provide these functions for them. We are unaware of empirical evidence to assess this hypothesis.

33 For example, if existing aspirin manufacturers had exclusive dealing arrangements with all available drugstores, a new entrant could not set up a new drugstore chain. It could, however, attempt to convince some drugstores to defect and sell its brand instead of their previous brands.

34 See, e.g., Joyce Beverages of New York, Inc. v. Royal Crown Cola Co., 555 F. Supp. 271 (S.D.N.Y. 1983); Sulmeyer v. Coca-Cola Co., 515 F.2d 835 (5th Cir. 1975); L. White, The Automobile Industry 
clusive distribution creates both efficiencies and market power, one would not necessarily wish to prohibit the practice.

Steiner has argued that restricted distribution (especially in combination with RPM or substantially equivalent non-price vertical restraints on leading brands) has also frequently delayed efficiency-enhancing reallocations of functions among vertical stages and hindered the diffusion of retailing efficiencies, at a great loss to consumers. ${ }^{35}$ For example, he argues that key manufacturers have been reluctant to sell to innovative, lower-cost retailing institutions (such as department stores and general mail-order houses in the mid-nineteenth century and discount stores in more recent years), even when the new retailers were more efficient than existing retailers and offered comparable

SINCE 1945, 147-52 (1971). In automobiles, some poor-selling U.S. and European models have had problems obtaining exclusive dealers. However, the Japanese manufacturers in general did not have that problem when they entered the U.S. market. This combination of experiences makes one wonder whether the problem is in obtaining distributors or retailers or in producing a high-quality product at a competitive price. Large economies of scale in bottling, selling, and distributing complicate the problem for soft drink manufacturers with small market shares. These allegations were important in the Commission's recent soft drink merger cases. See, e.g., Memorandum of Points and Authorities in Support of Plaintiff Federal Trade Commission's Complaint for a Preliminary Injunction 22-24 (June 30, 1986), Federal Trade Commission v. Coca-Cola Co., Civ. 86-1764 (D.D.C. 1986). The court granted a preliminary injunction, and the parties abandoned the attempted acquisition; 641 F. Supp. 1128 (D.D.C. 1986), vacated on grounds of mootness and remanded with instructions to dismiss, No. 86-5542 (D.C. Cir. Mar. 21, 1987). See also Boston Consulting Group, The Future of the Soft Drink Industry 1985-1990 (undated; c. 1984) (unpublished manuscript).

35 Steiner, Basic Relationships in Consumer Goods Industries, 7 Research in Marketing 165 (J. Sheth ed. 1984); R. Steiner, Vertical RestrainTS AND ECONOMIC EFFICIENCY 13-24 (Federal Trade Commission, Bureau of Economics Working Paper No. 66, 1982). Steiner argues that intrabrand competition for a "strong brand" reinforces interbrand competition and that vertical restraints on a "strong brand" tend to reduce interbrand competition and thereby have anticompetitive effects. The more common analysis is that interbrand and intrabrand competition are substitutes-i.e., intrabrand competition is unnecessary when interbrand competition is strong. He agrees with the consensus analysis that vertical restraints on "weak brands" tend to be procompetitive. 
services. When the government has forced the manufacturer of a leading brand to broaden its distribution and stop maintaining retail prices, the resulting intrabrand competition has also forced competing manufacturers to lower their prices and retail margins. Steiner argues that these interventions have substantially increased consumer welfare. ${ }^{36}$

3. FACILITATING COLLUSION Vertical restraints, especially in combination, may facilitate collusion. Telser has argued that a combination of RPM, exclusive dealing, standardized markups, and agreements not to raid competitors' dealers may greatly facilitate a manufacturers' cartel. The absence of some of these "ancillary" restraints would make an anticompetitive effect far less likely. ${ }^{37}$ Similarly, Pittman argued that exclusive dealing and

36 Steiner, The Nature of Vertical Restraints, 30 AntITrust Bull. 143 (1985), mentions in particular FTC interventions against Corning Glass ovenware and Levi Strauss men's jeans as prime examples. Oster, The FTC v. Levi Strauss: An Analysis of the Economic Issues, in R. LAFFERTY, R. LANDE \& J. KIRKWOOD, supra note 20, at 47, concurs in this interpretation of the Levi Strauss case.

A countervailing efficiency explanation for a reluctance to sell to discounters is that retailers provide and pay for much of the promotion. Retailers can recover the promotional costs only if the manufacturer limits the number and type of retail outlets covering the product. See, e.g., Marvel \& McCafferty, supra note 19. Opening the market to all retailers may lower price, but at the expense of promotional services. Customers do not necessarily prefer lower prices with fewer services. See, e.g., Hamilton, Why Rivals Are Quaking as Nordstrom Heads East, Business WeEK, June 15, 1987, at 99 (Nordstrom is enormously successful in its department stores with a strategy of providing superior service at upscale prices). For another example, skeptics interpret the increase in short-run profitability of Corning and Levi after FTC complaints as these firms cashing in the quality reputations that they had earned from vertical restraints-at a cost of lower long-run profitability.

Steiner answers that the sharp increase in the firms' stock prices after the FTC's legal victories is good evidence that ending restricted distribution and RPM raised the firms' long-run profitability. Moreover, he maintains that the proper measure is whether consumers, not Corning and Levi Strauss, gained.

37 Telser, supra note 18 , at $96-99$. 
tying reinforce each other and increase the probability of anticompetitive effects. ${ }^{38}$ Steiner also argued that selective distribution combined with exclusive dealing might make interbrand comparisons more costly, especially for products purchased infrequently, by making side-by-side product quality and price comparisons difficult. ${ }^{39}$ Because each store would carry only one brand, exclusive dealing combined with restricted distribution would also increase consumers' costs of making intrabrand price comparisons. Both effects would tend to raise retailers' margins or enable manufacturers to raise prices.

These approaches, while intuitively plausible, have not been formalized into theoretical models. Most theoretical analysis focuses on individual restraints. The combination of two vertically related markets complicates modeling substantially; each additional vertical restraint adds to the complexity. ${ }^{40}$ In short, substantial theoretical complexities inhibit analysis of the effects of packages of vertical restraints in oligopoly.

4. RAISING RIVALS' COSTS An emerging literature argues that one or more firms can use vertical restraints (and other practices) to raise rivals' costs and thereby induce price increases that reduce consumer welfare. ${ }^{41}$ Under special conditions, vertical restraints may enable a firm or group of firms to raise their rivals' costs for important inputs or distributional services proportionately more than they raise the costs of the initiating

38 Pittman, supra note 2.

39 Steiner, supra note 36 , at $183-87$.

40 There is also neither a natural initial value for conjectural variations nor a natural way for vertical control to change the conjectures. Mathewson \& Winter are pioneers in the complex analysis of packages of vertical restraints. See, e.g., Mathewson \& Winter, An Economic Theory of Vertical Restraints, 15 RAND J. ECON. 27 (1984).

41 See Krattenmaker \& Salop, supra note 29 , and the sources they cite. 
firm(s) ${ }^{42}$ Such strategic activity may inhibit the competitive viability of existing rivals and make new entry more difficult.

5. PRODUCT DIFFERENTIATION EFFECTS What happens when several manufacturers simultaneously use vertical restraints to encourage their dealers to enhance product differentiation? Some of the promotion may be demand-diverting (switching customers among brands) rather than demand-creating (encouraging additional sales for the product category). ${ }^{43}$ Exclusive dealing to encourage product differentiation can also change retailers from valuable sources of fairly impartial information on the comparative qualities of competing brands to biased advocates for a single brand. This effect can have adverse consumer protection ramifications. Aside from this effect, when vertical restraints encourage dealers to provide demand-enhancing services for a higher price, the welfare effects are ambiguous and depend on a comparison of the effects on marginal and inframarginal consumers. ${ }^{44}$

42 Two of the necessary conditions are market power by the firm or group imposing the restraint and significant barriers to entry into the affected market. See Vertical Guidelines, supra note 16, § 3.22; and Krattenmaker \& Salop, supra note 29, passim, for discussions of some of the necessary conditions for some hypothesized instances of raising rivals' costs. Even when vertical restraints raise the costs of some firms, they may also generate efficiencies. The overall effect of vertical restraints that raise rivals' costs can therefore be procompetitive, anticompetitive, or innocuous, depending on the comparative magnitude of efficiency and anticompetitive effects. Vertical restraints that raise the costs of rival firms are therefore not necessarily bad. Since raising rivals' costs cases often require a trade-off of efficiency and anticompetitive effects, the task of establishing appropriate policy guidelines is complex. Economists have not yet worked out all the necessary and sufficient conditions for actions that raise rivals' costs to result in higher prices to consumers or decreased economic efficiency.

43 For example, Steiner, supra note 35 , at 174-77, who considers demand-diverting expenditures socially wasteful, analyzes this situation as a prisoners' dilemma.

44 See, e.g., Comanor \& Kirkwood, Resale Price Maintenance and Antitrust Policy, 3 Contemp. Pol'y Issues 9 (1985). 


\section{The Vertical Restraints Guidelines}

The DOJ Guidelines implement the dominant current economic analysis of vertical restraints by quickly and clearly dismissing concern with non-price vertical restraints except in a few situations. However, they apparently treat "airtight" non-price vertical restraints as homogeneous, nonadditive factors and therefore do not address economic analysis that suggests complex effects from combinations of vertical restraints.

The guidelines use a three-stage process to shorten review of vertical control. They explicitly discuss Step One (the structural analysis) and Step Two (the analysis of competitive effects). However, an initial definitional stage (which for symmetry we call "Step Zero") is equally important. The definitional and structural tests restrict analysis of difficult questions of actual competitive impact to situations where anticompetitive effects are significantly plausible. This methodology eliminates expensive, lengthy rule of reason analysis in most investigations.

Beginning with Step Zero, the guidelines separate vertical restraints into "pigeonholes" for easy analysis. The main pigeonholes are vertical or horizontal; non-price or price; unilateral or concerted; intrabrand or interbrand; and airtight or nonairtight. Although these distinctions are not always easy in practice, the guidelines simplify them by generally resolving all definitional doubts in favor of more lenient treatment.

The first distinction-vertical or horizontal-is important, because the guidelines reflect the Administration's current practice of viewing horizontal restraints as highly suspect and vertical restraints as virtually always legal. Some situations, however, have both vertical and horizontal aspects. To suggest a few possibilities: a manufacturer may communicate with its dealers about vertical restraints; a manufacturer may sell both directly to final purchasers and through dealers ("dual distribution"); different manufacturers may all use the same non-price vertical restraint (or combination of restraints); or all the dealers of a manufacturer's brand may jointly urge (compel) the manufac- 
turer to impose territorial restrictions on its dealers. In such cases, is there an agreement over the restrictions, and if so, is it vertical (manufacturer-dealer) or horizontal (a cartel of direct competitors, such as dealers or manufacturers) $?^{45}$ The precise facts are critical, and small differences in the perception of these facts can often induce one to change his conclusion. The guidelines, however, consider these agreements vertical rather than horizontal in the absence of strong evidence of a horizontal, interbrand conspiracy.

The distinction between RPM (per se illegal) and non-price vertical restraints (typically legal) can also be subtle. The guidelines caution:

[B]efore characterizing a practice as a price restraint subject to per se treatment, there must be an agreement between a supplier and its distributors as to resale prices. . . . if a supplier adopts a bona fide distribution program embodying both nonprice and price restraints, the Department will analyze the entire program under the rule of reason if the nonprice restraints are plausibly designed to create efficiencies and if the price restraint is merely ancillary to the nonprice restraints. ${ }^{46}$

The third distinction, unilateral versus concerted, follows a long legal tradition of permitting both RPM and non-price

45 For some illustrations of the ambiguities of these distinctions, see Rothery Storage \& Van Co. v. Atlas Van Lines, Inc., 792 F.2d 210 (D.C. Cir. 1986); General Leaseways, Inc. v. National Truck Leasing Ass'n, 744 F.2d 588 (7th Cir. 1984); Red Diamond Supply, Inc. v. Liquid Carbonic Corp., 637 F.2d 1001 (5th Cir. 1981); United States v. Topco Assocs., 405 U.S. 596 (1972); United States v. Sealy, Inc., 388 U.S. 350 (1967); and United States v. General Motors Corp., 384 U.S. 127 (1966). The guidelines do not always reflect case law here. See, e.g., Judge Posner's recent decision in General Leaseways that dealers' joint activities to urge (compel) a manufacturer to impose territorial restraints on them was per se illegal. His decision used both vertical and horizontal precedents. Compare these decisions to the Vertical Guidelines, supra note $16, \S 2.1$, quoted infra at note 49 , and to A. Abbott, supra note 17, at 3 , also quoted infra at note 49 .

46 Vertical Guidelines, supra note $16, \S 2.3$. 
vertical restraints instituted unilaterally by a manufacturer. ${ }^{47}$ The Department follows precedents ${ }^{48}$ that require clear evidence of joint manufacturer-dealer activity to infer concerted (potentially illegal) rather than unilateral (legal) behavior.

The distinction between intrabrand and interbrand competition reflects the view that purely intrabrand vertical restraints pose little threat to competition and should therefore usually be legal. The language comes very close to characterizing all nonprice vertical restraints as intrabrand and therefore legal, except in the presence of strong proof of a horizontal conspiracy. ${ }^{49}$

47 Monsanto Co. v. Spray-Rite Service Corp., 104 S. Ct. 1464 (1984); Russell Stover Candies, Inc. v. Federal Trade Commission, 718 F.2d 256 (1983); United States v. Colgate \& Co., 250 U.S. 300 (1919).

48 E.g., Yentsch v. Texaco, Inc., 630 F.2d 46 (2d Cir. 1980); Arnott v. American Oil Co., 609 F.2d 873 (8th Cir. 1979), cert. denied, 446 U.S. 918 (1980); and other cases cited supra note 47.

49 Sims \& Lande, supra note 5, make the same point. In the words of the guidelines, "Even though, in some cases, intrabrand restraints can be characterized as horizontal agreements because competing dealers act in concert, it is inappropriate to treat intrabrand agreements in the same manner that other horizontal agreements are treated. Such restraints can have no effect that could not also be obtained through the unilateral action of the manufacturer of the particular brands in question. An intrabrand agreement should not create the inference that a restraint is being 'imposed' on a manufacturer." Vertical Guidelines, supra note 16, § 2.1. A. Abbott, supra note 17, at 3, is even more explicit: "the Justice Department will treat all nonprice intrabrand restraintsthat is, restraints involving dealers or manufacturers of the same brand-as vertical rather than horizontal." The guidelines have apparently adopted Professor Liebeler's analysis. See Liebeler, Intrabrand "Cartels" Under GTE Sylvania, 30 U.C.L.A. L. Rev. 1 (1982). The distinction between intrabrand and interbrand is thus virtually identical to that between horizontal (a dealers' cartel) and vertical (a manufacturerimposed intrabrand restraint). See supra note 45 . Factually, it is not always clear which side has imposed the restraints on the other. See, e.g., Red Diamond Supply, Inc. v. Liquid Carbonic Corp., 637 F.2d 1001 (5th Cir. 1981); United States v. Topco Assocs., 405 U.S. 596 (1972); United States v. Sealy, Inc., 388 U.S. 350 (1967). The authors of the guidelines believe that dealers can rarely force a manufacturer to impose vertical restraints, so they have a very high evidentiary requirement to consider intrabrand restraints as horizontal rather than vertical. 
The fifth distinction separates "airtight" restraints (exclusive dealing, exclusive territories, and tying) from "nonairtight" vertical restraints (such as selective distribution, locational clauses, and profit-passover arrangements) by arguing that the courts have typically found nonairtight restraints to be legal (sec. 2.5). The guidelines only apply, therefore, to airtight forms of vertical control "whose legal status remains somewhat uncertain" (sec. 2.5). The Step One and Step Two analyses apply only for exclusive dealing and exclusive territories; because of legal considerations, there is a separate methodology for tying (see below).

The Department's definitional methodology, then, quickly disposes of most vertical restraints: all unilateral behavior and nonairtight vertical restraints are legal, and virtually all intrabrand non-price vertical restraints are legal in the absence of strong evidence of a manufacturers' or possibly a dealers' cartel. The market structure tests (Step One) apply only for patterns of exclusive dealing or exclusive territories across manufacturers and their dealers that affect competition among different manufacturers' brands.

For these restraints, the guidelines use the most objective, easily determined structural factors that affect the likelihood of anticompetitive effects. The guidelines propose legality for nonprice vertical restraints for small firms (condition 1), unconcentrated markets (conditions 2 and 3), and markets where a large proportion of the sales are by firms not using "the same vertical restraint" (conditions 2 and 4). The Department therefore permits vertical restraints where any of the following conditions hold (sec. 4.1):

(1) the firm employing the restraint has a share of the relevant market of 10 percent or less;

(2) the VRI [sum of the squares of the market shares of the firms using the restraint] is under 1200 and the coverage ratio [percentage of each market using the restraint] is below 60 percent in the same (e.g., supplier or dealer) relevant market;

(3) the VRI is under 1200 in both relevant markets; or

(4) the coverage ratio is below 60 percent in both relevant markets. 
If none applies, the Department proceeds to Step Two, a more thorough examination of competitive effects. However, the Department will not challenge exclusive dealing or exclusive territories agreements if entry is easy at both levels or if the firm using the vertical restraint has entered within the preceding two years. ${ }^{50}$

For exclusive dealing or exclusive territories failing the structural analysis of Step One or the entry tests, a "structured rule of reason" test considers concentration, other firms' use of vertical restraints, the industry's tendency toward collusion, the extent of the vertical restraints' exclusionary effects, the "intent" of the firms, and any likely procompetitive effects. ${ }^{\text {s1 }}$ The guidelines are only minimally helpful for vertical restraints that reach this part of Step Two, because the Department does not explain how it proposes to weigh all these factors to determine overall legality.

The accompanying figure summarizes the guidelines' methodology. The definitional stage (Step Zero) and Step One apply a series of six filters. The guidelines presume unilateral behavior, intrabrand restraints, and nonairtight restraints to be legal. They then dismiss concern if the market is unconcentrated, the coverage ratio is not overly high, or the firm's market share is low. Step Two continues with two more filters, to dismiss concern if the firm is a new entrant or if entry barriers are low. Only when vertical restraints pass through all eight filters and end up in the

50 The Merger Guidelines, supra note $31, \S 3.3$, suggest that the Department will generally use a two-year cutoff to determine when entry conditions are sufficiently difficult to cause concern. Unfortunately, the Vertical Restraints Guidelines are not as specific in defining entry conditions. Moreover, the entry-condition standard goes one step further: if conditions of entry are "easy" at the stage where anticompetitive effects would have to occur, then the government will not challenge non-price vertical restraints, even if entry is difficult at the other level.

51 For example, the guidelines explicitly recognize the possibility of firms using vertical restraints to raise rivals' costs. See supra Section II.B.4. The Vertical Guidelines, supra note 16, $\$ 3.22$ ("Excluding Rivals"), discuss in detail two scenarios by which vertical restraints "may have the effect of excluding rivals by prohibitively raising either their cost of a vital input or their cost of distribution." Unfortunately, there is no discussion of how one is to determine whether vertical restraints have undesirable effects that the government might wish to challenge. 
The Methodology of the DOJ Vertical Restraints Guidelines

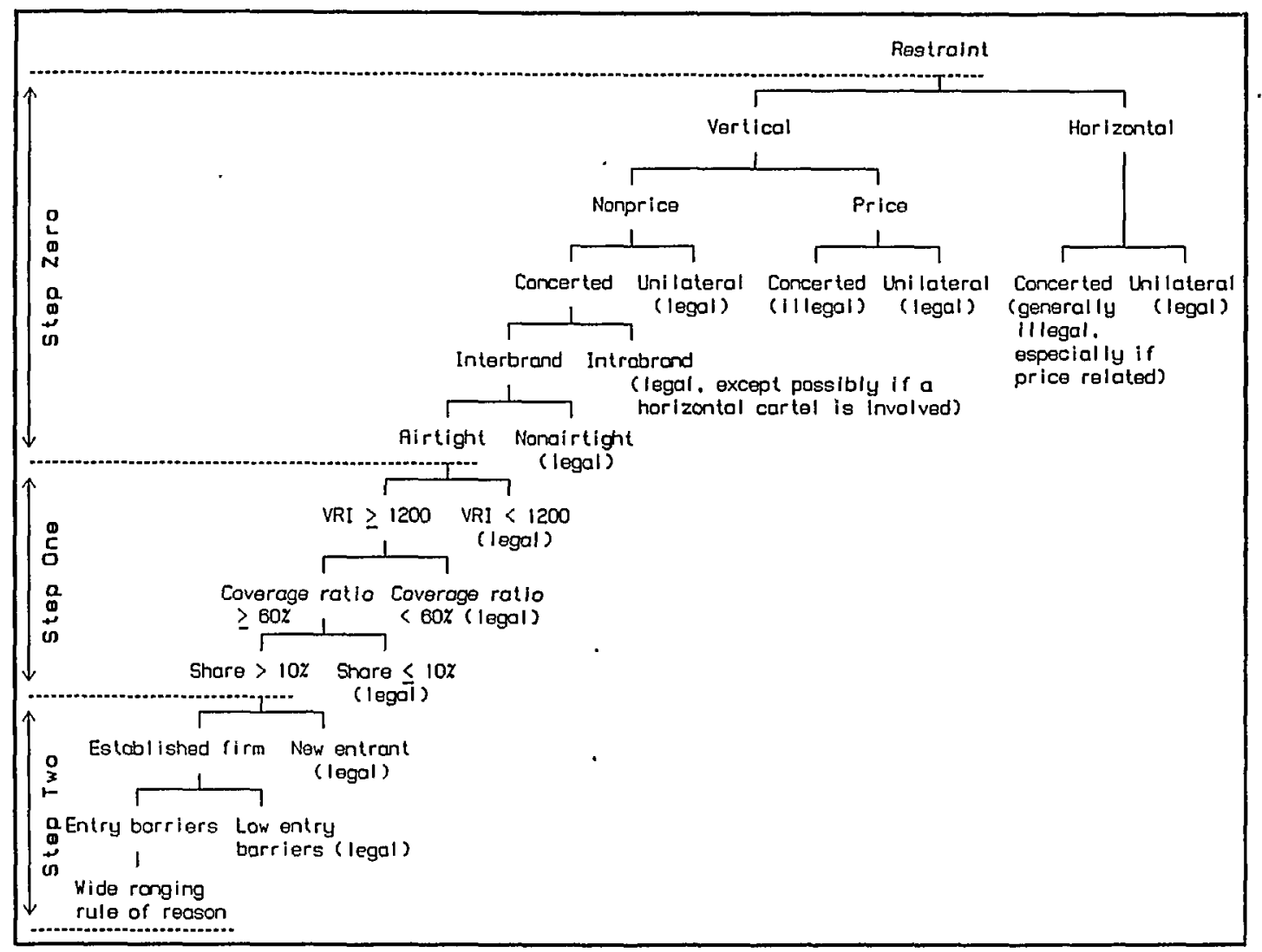


bottom, left channel does the analysis go further. With so many escape routes, one would expect the Department rarely to reach the rule of reason portion of Step Two.

The guidelines treat tying separately (sec. 5), perhaps because the courts have always been more strict with tying than with other non-price vertical restraints. The guidelines' analysis of tying is less clearly articulated and therefore less useful than their treatment of other restraints. The guidelines express no concern with tying by a firm with a share of 30 percent or less of the tying product's market, unless "the tying arrangement unreasonably restrain[s] competition in the market for the tied product." If the firm's share exceeds 30 percent, the Department considers tying per se illegal if the firm has "dominant" market power and subject to a rule of reason analysis (of whether the "tie unreasonably restrain[s] competition in the tied product['s] market") otherwise..$^{52}$

This prescription is not very helpful. For firms with market shares of 30 percent or less, the guidelines say that tying is usually but not completely safe; for firms with shares in excess of 30 percent, there is little guidance. Although the guidelines do not legitimize tying by firms with small market shares, this Administration is highly unlikely to challenge tying that involves only private, unregulated firms. The guidelines provide no analysis of why tying, even by a cartel or monopolist, could ever be anticompetitive. However, the majority opinion in Hyde, which may have condemned certain instances of tying because of wealth-transfer effects, probably constrained the authors of the guidelines from proposing per se legality for tying. ${ }^{53}$

For exclusive dealing and exclusive territories, the guidelines' almost exclusive concern is cartelization; for tying, the sole concern is monopolization. Since it is often difficult to distin-

52 This analysis comes from the Court's opinion in Jefferson Parish Hospital District No. 2 v. Hyde, 104 S. Ct. 1551 (1984).

53 See Sims \& Lande, supra note 5. 
guish between exclusive dealing and tying, ${ }^{54}$ this difference is odd. Analytically, there is no reason for different standards for tying than for other vertical restraints.

\section{Policy considerations and the impact of the guidelines}

The complexity of the economic effects of vertical restraints is a challenge for antitrust policy. Economic theory supports both procompetitive and anticompetitive interpretations of vertical restraints, although the current prevalent opinion is that procompetitive scenarios are generally more credible. Ideally, empirical analysis would determine whether vertical restraints were usually procompetitive or anticompetitive in net effect. Unfortunately, the facts known about a practice are frequently consistent with both interpretations. ${ }^{55}$ Indeed, the more compelling either the procompetitive or the anticompetitive scenario, the greater the likelihood that firms representing a large portion of the industry will find the same or similar combinations of vertical restraints in their best interests. Empirical analysis is thus difficult, and careful empirical evaluation of vertical restraints is rare. ${ }^{66}$ Because of different perspectives and complexity of the analysis, scholars will differ in their interpretations. ${ }^{57}$ The guidelines' claim (sec.

\section{2.}

54 See, e.g., Pittman, supra note 2; P. ArEEDA, supra note 1, at 809-

5s For example, when demand-enhancing services of retailers are important to a product's success, manufacturers may find vertical controls such as restricted distribution and possibly exclusive territories important. The more important such retailer services, the more likely that virtually all manufacturers will use the same or similar packages of vertical restraints. However, the more brands that rely heavily on retailer promotion, the greater the likelihood that some of the promotional activities will be demand-diverting. This scenario can therefore have anticompetitive effects only if several firms simultaneously attempt to use vertical restraints to generate efficiencies.

56 For discussions of the few available examples, see R. LAFFERTY, R. LANDE \& J. KIRKWOOD, supra note 20; T. OvERSTREET, supra note 20.

57 For one example, see supra note 36. 
3.2) that "vertical restraints generally have a procompetitive or competitively neutral effect" relies more on theory than on empirical evidence. We simply do not know the extent of anticompetitive results. ${ }^{58}$

An optimal antitrust policy would minimize the expected cost of the three types of policy errors. ${ }^{59}$ With respect to vertical restraints, these errors are:

Type 1 error: stopping desirable vertical restraints (errors of commission).

Type 2 error: permitting undesirable vertical restraints (errors of omission).

Type 3 error: incurring excessive costs of enforcement, litigation, and business uncertainty.

In a world of expensive information, some policy errors are inherent; the design of the enforcement policy determines the actual mix. "Brightline" enforcement would minimize Type 3 error at an inherent cost of Types 1 and 2 error, the choice of the

58 The Vertical Guidelines, supra note $16, \S 4$, continue: "even those vertical restraints not 'screened out' in Step One are unlikely to have anticompetitive effects. . . "However, the basis of this prediction is entirely theoretical. Moreover, many price-fixing cases have arisen in markets (such as paper-box converting, road building, and trash hauling) where most economists would predict that price-fixing could not have any significant effect. E.g., compare Elzinga, New Developments on the Cartel Front, 29 ANTITRUST Bull. 3 (1984), and O. Williamson, Markets and Hierarchies: ANalysis and ANTITRUST IMPLiCATIONS 234-47 (1975), with Sonnenfeld \& Lawrence, Why Do Companies Succumb to Price Fixing?, 56 HaRv. Bus. Rev. 145, 146-47 (1978). Price-fixing conspiracies sometimes persist for many years and have surprisingly large effects on prices. For example, a former high official in the Justice Department informally estimated that the bid-rigging conspiracies that the Department had detected had raised prices for road repairs by an average of around 10 percent.

59 For further discussion, see Fisher \& Lande, Efficiency Considerations in Merger Enforcement, 71 CALIF. L. REv, 1580, 1670-77 (1983); for a formalization, see Fisher \& Sciacca, supra note 19, at 72-75. For another, similar discussion, see Easterbrook, Vertical Arrangements and the Rule of Reason, 53 ANTITRUST L.J. 135, 157-59 (1984). 
threshold level of legality determining the trade-off between Types 1 and 2 error. The opposite, unstructured rule of reason with no explicit standards, can lead to very substantial Type 3 error in an attempt to reduce Types 1 and 2 error. "Bright lines" work well when legal and illegal behavior are clearly distinguishable or when the (direct and indirect) litigation costs are high. The strongest case for a rule of reason is where distinctions vary critically with the nuances of the restraint in question and litigation and uncertainty costs are low. With vertical restraints, however, competitive effects are complex, and expert witnesses often disagree over the probable magnitudes of efficiency, anticompetitive, and thus net effects of combinations of vertical restraints. We therefore cannot be confident that judges will determine individual cases more accurately than a brightline approach would. There is no guarantee that a full rule of reason approach would decrease the sum of Types 1 and 2 error, although it would certainly raise Type 3 error in comparison to an approach containing presumptions and bright lines. The strongest argument in favor of per se legality for all vertical restraints is that any other legal standard would lead to unacceptably large Type 3 error, that the inherent costs of business confusion and litigation are virtually certain to be greater than the maximum conceivable Type 2 error. $^{60}$

60 Courts would have great difficulty in evaluating the desirability of permitting any given package of vertical restraints. Courts have varied widely in how they have handled complex economic investigations. Some have refused to balance procompetitive and anticompetitive effects and resolved all doubt on the side of strict enforcement of antitrust laws; more recently, some courts have been more willing to attempt difficult rule of reason trade-offs of procompetitive and anticompetitive effects. For example, the Court has justified per se rules in large part to shield the courts from "ramb[ling] through the wilds of economic theory." United States v. Topco Assocs., 405 U.S. 596, 610 (1972). Perhaps the classic statement of the inability of the courts to trade off efficiency and anticompetitive effects of vertical restraints on a case-by-case basis is Justice Frankfurter's majority opinion in Standard Oil Co. v. United States, 337 U.S. 293 (1949), discussed in depth in L. Sullivan, HANDBOOK OF THE LAW OF ANTITRUST 473-76 (1977). For a similar argument in the context of mergers, see United States v. Philadelphia Nat'l Bank, 374 U.S. 321,371 (1963). However, the courts have attempted 
The guidelines offer a mixed strategy. The Step Zero definitions and Step One structural analysis set out objective, clear zones of legality. For restraints that pass the guidelines' definitional and structural standards for legality (and for new entrants and industries where entry conditions are easy), the guidelines minimize Types 1 and 3 error but may risk excessive Type 2 error. For restraints above the threshold standards, however, the guidelines string together a long list of subjective factors without providing clues to their weight, balance, or influence. ${ }^{61}$ For restraints in this zone, the guidelines promise substantial Type 3 error. However, most antitrust practitioners predict that the current Administration will not challenge vertical restraints except possibly in conjunction with strong evidence of actual horizontal collusion or involvement by some unit of government. ${ }^{62}$ Indeed, this Administration has not supported any vertical restraints cases. The Justice Department has filed no vertical cases since President Reagan's inauguration, and the Commission has issued only four complaints, all before Reagan appointees attained a majority. ${ }^{63}$ The overall effect of this enforcement

difficult rule of reason trade-offs in other cases. See, e.g., Graphic Products Distributors, Inc. v. Itek Corp., 717 F.2d 1560 (11th Cir. 1983); Broadcast Music v. Columbia Broadcasting System, 441 U.S. 1 (1979); In re Coca-Cola Co., 91 F.T.C. 517 (1978), remanded for dismissal following passage of legislation that permitted the practices in question, sub nom. Coca-Cola Co. v. Federal Trade Commission, 642 F.2d 1387 (D.C. Cir. 1981). Moreover, the recent trend is toward rule of reason. See supra note 4.

61 The treatment of tying has a similar deficiency; there is no definition of what constitutes "unreasonably" restraining competition in the market for the tied product or determines when a firm with a greater than 30 percent share of the tying product has "dominant" market power.

62 For example, there is general "recognition that the Department has not really been in the vertical restraints enforcement business for a decade or so." See Sims \& Lande, supra note 5, at 16.

63 The Department of Justice's last three vertical cases involved RPM: United States v. Mack Trucks, Inc., Civ. 81-0102 (E.D. Pa. filed Jan. 12, 1981), dismissed without prejudice (July 8, 1981), 4 TRADE REG. REP. (CCH) I 45,081, at 53,468-69; United States v. Cuisinarts, Inc., 
strategy, then, is to minimize Type 1 error attributable to the federal government. ${ }^{64}$ Under a rule of reason analysis that emphasizes the legality of non-price vertical restraints in nearly all situations, Type 1 error could only arise as a result of incorrect judgment. ${ }^{65}$

The choice of threshold levels of legality (which determines the trade-off between Types 2 and 3 error) is guaranteed to provoke disagreement. Some economists and attorneys believe that vertical restraints have anticompetitive effects in the absence

Crim. H-80-49 (D. Conn. 1980), 4 Trade Reg. Rep (CCH) \ 45,080, at 53,436-37, and Civ. H-80-559 (D. Conn. 1981), 1981-1 Trade Cas. (CCH) 63,979, at 76,067. Cuisinarts pleaded nolo contendere and paid a fine of $\$ 250,000$ in the criminal case. The civil case ended in a consent. We thank Ralph Justus for providing information about Justice Department cases.

The Commission issued four complaints and accepted simultaneous consents in vertical restraints cases before Reagan appointees attained a majority on the Commission. The two most recent complaints arose from one matter involving an intrabrand cartel. In re Great Dane Trailers, Inc., 102 F.T.C. 1307 (1983); and In re Great Dane Distributor Council, 102 F.T.C. 1315 (1983). Chairman Miller and Commissioner Douglas, the only Reagan appointees at that time, dissented in these matters. With respect to RPM, the Commission accepted consents in two cases when President Reagan had made only one appointment (Chairman Miller). See In re Onkyo, USA, Corp., 100 F.T.C. 59 (1982); In re Germaine Monteil Cosmetiques Corp., 100 F.T.C. 543 (1982). We thank Linda Knight-Stewart for providing information about Commission vertical restraints cases.

64 Of course, the Department can only affect overall Type 1 error by convincing the courts to adopt its analysis.

65 The Justice Department has offered to file amicus briefs for defendants in private vertical restraints cases to help convince courts to adopt its analysis. See BNA, Distribution Seminar Speakers Differ on Current Vertical Law, Counseling, 48 Antitrust \& Trade Reg. Rer. 716, 719 (Apr. 25, 1985) (quoting Special Assistant to the Attorney General Alden F. Abbott). The heavy evidentiary burden on the prosecution in Step Two further reduces Type 1 error. If the courts held the government to the guidelines and gave it the burden of proof, it would be extremely difficult for the government to prosecute a vertical restraints case successfully. 
of attempted collusion and monopolization frequently enough to justify enforcement concern. ${ }^{66}$ Because of the complexity of vertical restraints and the paucity of reliable empirical evidence, this disagreement with the guidelines rests largely on faith. One's preferred legal standard also depends on one's view of the proper goals of antitrust. The current Administration views efficiency considerations as the sole rationale for antitrust enforcement; an alternative interpretation is that Congress passed the antitrust laws to prevent wealth transfers from consumers to firms with market power. ${ }^{67} \mathrm{~A}$ standard based on wealth transfers implies more antitrust enforcement than does a standard based on economic efficiency. Regardless, nearly all antitrust scholars should be comfortable with a presumption of legality for vertical restraints for firms with market shares of 10 percent or less, for new entrants, and for industries where firms using similar restraints account for no more than 60 percent of the sales and there is no evidence of horizontal collusion. ${ }^{68}$

Implementing guidelines always causes confusion, and the Vertical Guidelines are no exception. ${ }^{69}$ For example, consider a

\section{See supra Section II.}

67 Compare, e.g., the efficiency view in Baxter, Responding to the Reaction: The Draftsman's View, 71 CALIF. L. Rev. 618, 619-21 (1983), - with the wealth-transfer view in Lande, Wealth Transfers as the Original and Primary Concern of Antitrust: The Efficiency Interpretation Challenged, 34 HASTINGS L.J. 65 (1982). The more heavily one weighs wealth transfers, the greater one's concern for the price-increasing potential of vertical restraints. For illustrations of this point, see A. FisHer, F. JOHNSON \& R. LANDE, supra note 28 . When vertical restraints permit price increases to encourage dealer-provided services, there can be an evidentiary morass to separate procompetitive from anticompetitive portions of any price increase. See supra Section II.

68 There will probably be less agreement on the policy of legality for vertical restraints in the absence of high concentration (where the VRI does not exceed 1200). For example, many price-fixing cases involve industries with low concentration (i.e., an HHI far below 1000). See supra note 58.

69 Some members of the private bar have protested the unnecessary complexity of introducing the VRI. Sims \& Lande, supra note 5, sug- 
moderately concentrated market with relatively difficult entry conditions. Suppose that 50 percent of the market had been using a vertical restraint and that another firm adopted a similar restraint, bringing the coverage ratio above 60 percent. Should the government (or the private bar) challenge the newest firm to use the restraint, the industry's largest firm, or all firms with more than 10 percent of the market? Indeed, given the variety of vertical restraints, when should one include different restraints with similar effects in calculating the coverage ratio ${ }^{70}$ The guidelines talk in terms of "the" restraint, but economic analysis" suggests that restraint packages pose more anticompetitive risks than a single restraint. Should the standards tighten as firms multiply restraints?

The roles of private and state enforcement further complicate evaluation. The guidelines are only a statement of enforcement policy; they are not the law. ${ }^{72}$ Because a substantial majority of vertical restraint cases have been private, ${ }^{73}$ the guidelines can only

gested that the Department could have issued the same guideline thresholds by using the Herfindahl index (HHI) and a coverage ratio to replace the VRI.

70 For example, suppose that one firm uses tying, a second uses exclusive dealing, and a third uses a combination of exclusive territories and a refusal to sell to discounters. The firms presumably use these vertical restraints to accomplish very similar goals. Whose market shares should one include in calculating the VRI?

71 See supra Section II.

72 See, e.g., House Judiciary Comm., Vertical Restraints Guidelines Resolution, H.R. Rep. No. 399, 99th Cong., 1st Sess. (1985), reprinted in TRADE REG. ReP. (CCH) No. 733, pt. 2 (Dec. 9, 1985); House Judiciary Committee, supra note 17 . At least one judge recently made precisely this point in response to a defendant's argument that its vertical restraints were legal under the guidelines. See infra note 86 .

73 In every year between 1970 and 1984, private antitrust cases filed ranged between 90.1 and 95.6 percent of the sum of U.S. government and private cases. See Salop \& White, Economic Analysis of Private Antitrust Litigation, 74 GEO. L.J. 1001, 1002 (1986). In their sample of all private antitrust cases filed in the five federal districts during 1973-83, 
affect Types 1, 2, and 3 error by influencing the courts. Although " $[t]$ here is a trend toward legality of all nonprice vertical restraints," ${ }^{74}$ some courts apply more stringent standards. In counseling clients, James F. Rill, current Chairman of the Antitrust Section of the American Bar Association, cautioned against "reliance on the Justice Department's vertical guidelines." other practitioner added that 90 percent of private vertical restraint cases are settled, often on stricter terms than the virtually per se legal guideline standards. ${ }^{76}$ And as more plaintiffs lose RPM and dealer termination cases, they are turning to state antitrust and tort laws with increasing success. ${ }^{77}$

A few years ago, economists and attorneys often criticized antitrust policy for a pathological concern over Type 2 error at an excessive cost in Type 1 error. In reaction to these excesses, the current Administration has raised the prosecutorial burdens that had led to excessive Type 2 error. ${ }^{78}$ The guidelines do reduce Type

Salop and White found that the primary or secondary allegation concerned vertical practices (vertical price-fixing, dealer termination, refusal to deal, tying, or exclusive dealing) in a majority of instances: between 54 and 81 percent each year during 1973-79 and between 41 and 58 percent each year during 1980-83. Id. at 1042. The average number of private cases per year that included vertical allegations dropped by approximately 40 percent from $1973-79$ to $1980-83$. Id. at 1002,1042 . For a discussion of another survey with similar results, see Fisher \& Sciacca, supra note 19 , at 104 n.2.

74 See BNA, supra note 65, at 716 (quoting James F. Rill of Collier, Shannon, Rill \& Scott, Washington, D.C.).

75 Id.

76 Id. at 717 (reporting comments by Harvey M. Applebaum of Covington \& Burling, Washington, D.C.).

77 Id. at 718 (reporting a presentation by Jay Greenfield of Paul, Weiss, Rifkind, Wharton \& Garrison, New York).

78 As an example in a related context, former Assistant Attorney General for Antitrust J. Paul McGrath implied that the Antitrust Division was using the higher evidentiary requirement of the Sherman Act to evaluate merger cases. He stated that repealing section 7 of the Clayton Act (which covers mergers) "would not change our enforcement policy at all." See Henderson, Baldrige Merger Plan Criticized, Washington Post, Mar. 3, 1985, at F1, F8. 
2 error by providing clear zones of proposed legality for vertical restraints. Many scholars, practitioners, and businessmen will be comfortable with this portion of the guidelines.

From the perspective of two years of experience, the guidelines have probably not been as influential as the Department had hoped and have therefore had only a modest effect in reducing Types 2 and 3 error. They have, however, generated controversy and political reactions, including two days of hearings by the Subcommittee on Monopolies and Commercial Law of the House Judiciary Committee. The House issued the subcommittee's report condemning the guidelines and attached to the Department's appropriations bill a resolution expressing "the sense of the House that the Vertical Restraints Guidelines ... are not an accurate expression of federal antitrust law or congressional intent, shall not be considered by the courts as binding or persuasive and should be recalled by the Attorney General."”9

The states' attorneys general agreed with the House that the federal government is no longer enforcing the law with respect to vertical restraints. This issue solidified the opposition of state attorneys general to the Administration's antitrust program; for the first time ever, they agreed unanimously on an antitrust policy issue. All 55 members of the National Association of Attorneys General (NAAG) endorsed a competing set of Vertical Restraints Guidelines and promised to increase their scrutiny of vertical restraints. ${ }^{80}$

The NAAG Guidelines differ significantly from those of the Justice Department, both in object and in specifics. ${ }^{81}$ The NAAG

79131 Cong. Rec. H11,391 (daily ed. Dec. 9, 1985). See also BNA, Congress Takes Affirmative Steps to Attack Vertical Restraints Guidelines, 49 Antitrust \& Trade Reg. Rep. 1019 (Dec. 12, 1985).

80 There are 55 members, including attorneys general representing the District of Columbia and various territories. National Association of Attorneys General, Vertical Restraints Guidelines (Dec. 4, 1985), reprinted in 5 TRADE Reg. ReP. (CCH) I 50,478 [hereinafter cited as NAAG Guidelines].

81 For a discussion of the NAAG Guidelines, see Baldwin, NAAG Issues Counter-Guidelines on Vertical Restraints, 7 ANTITRUst 22 (1986). 
Guidelines characterize existing case law from the point of view of prosecutors. Because the Supreme Court has issued only two substantive opinions on non-price vertical restraints in the past 15 years, ${ }^{82}$ and academic opinion has changed significantly, the case law has some inconsistencies and offers room for differences in interpretation. ${ }^{83}$ The NAAG Guidelines emphasize decisions favorable to prosecutors and warn the business community that state attorneys general will sometimes challenge restraints that do not violate the DOJ Guidelines. ${ }^{84}$ Since private plaintiffs use the same precedents, this warning is useful. ${ }^{85}$

82 Jefferson Parish Hospital District No. 2 v. Hyde, 104 S. Ct. 1551 (1984); and Continental T.V., Inc. v. GTE Sylvania, Inc., 433 U.S. 36 (1977).

83 Compare, e.g., the cases cited by the NAAG and those cited by the Department. Baldwin, supra note 81 , compares and evaluates the precedents urged in each set of guidelines.

84 With the assistance of Susan Beth Farmer, Assistant Attorney General, State of New York, we have located three cases that state attorneys general have already filed or argued under the NAAG Guidelines: Virginia v. Winslow, Chancery No. 20942 (Va. Cir. Ct., Prince William Cty., Feb. 20, 1987), 52 Antitrust \& Trade Reg. Rer. (BNA) 437 (Mar. 5, 1987); In re Thomas Bislow's, Inc., No. 481,875 (Ramsey Cty. [Minn.] D.C. Jan. 20, 1987) (assurance of discontinuance); and New York v. Anheuser-Busch, Inc., Civ. 86-2345 (E.D.N.Y. July 15, 1986), 51 Antitrust \& TRADE REg. ReP. (BNA) 108 (July 17, 1986). During the process of discovery in Anheuser-Busch, the New York Appellate Court held that purely vertical arrangements to allocate exclusive territorial distributorships are per se legal under the Donnelly Act. AnheuserBusch, Inc. v. Abrams, Nos. $28375 \mathrm{~N}, 28376 \mathrm{~N}, 28377 \mathrm{~N}, 28378 \mathrm{~N}$, 28379 N, 28380N (N.Y. App. Div., 1st Dep't, Mar. 5, 1987), 52 ANTITRUST \& TRADE REG. ReP. (BNA) 478, 489 (Mar. 12, 1987). We thank Phyllis A. Errico, Assistant Attorney General, Commonwealth of Virginia, for providing information on Winslow, and Sarah G. Mulligan, Special Assistant Attorney General, State of Minnesota, for providing information on Bislow's.

85 Many observers consider the DOJ Guidelines essentially a general-purpose amicus brief for defendants in vertical restraints cases. The NAAG Guidelines serve as a general-purpose amicus brief for prosecutors. 
The DOJ Guidelines have apparently only minimally affected private and state cases. Our computer search found only two opinions that cited the guidelines in their first 28 months. ${ }^{86}$ This number is surprisingly low considering that the Commerce Clearing House $(\mathrm{CCH})$ reported at least 100 vertical restraints decisions during this period. ${ }^{87}$ In contrast, courts routinely discuss the DOJ Guidelines in merger decisions. ${ }^{88}$

86 Miller Insituform, Inc. v. Insituform of North America, Inc., 605 F. Supp. 1125 (M.D. Tenn. 1985), cited the DOJ Guidelines twice, once with apparent approval on a patent issue, and once in passing (noting without comment the guidelines' view that tying arrangements "generally do not have significant anticompetitive potential"). In Will v. Comprehensive Accounting Corp., 776 F.2d 665 (7th Cir. 1985), Judge Easterbrook, an advocate for per se legality for all vertical restraints, favorably cited the guidelines' view that tying arrangements affecting less than 30 percent of a relevant market should be legal.

However, the reaction of Judge Smith in Virginia v. Winslow, Chancery No. 20942 (Va. Cir. Ct., Prince William Cty., Feb. 20, 1987), 52 Antitrust \& Trade Reg. Rep. (BNA) 437 (Mar. 5, 1987), may be common. In reaction to Winslow's argument that its behavior was legal under the guidelines, Judge Smith wrote: "The guidelines prepared by the Department of Justice in January of 1985 are, in my opinion, prepared simply as guidelines to assist in the efficient use of the resources of that department in prosecuting federal antitrust cases. They in effect advise the agents and lawyers in the Department of Justice of the types of cases they will prosecute. It is obvious from those guidelines that they do not prosecute all cases." Letter from H. Smith to Allen L. Jackson, Conrad M. Shumadine, and Richard R. Nageotte (Aug. 6, 1986).

87 We briefly reviewed the 160 listings in indexes to $\mathrm{CCH}$ Trade Cases, volumes 1985-1, 1985-2, 1986-1, and 1986-2, under "Exclusive Dealing," "Exclusive Rights," "Refusal to Deal," "Resale Price Maintenance," and "Tying" and counted only decisions that discussed issues treated in the Vertical Guidelines. We counted 96 decisions that we believe could have cited the guidelines. In addition, we added Pink Supply Corp. v. Hiebert, 1986-1 Trade Cas. (CCH) I 67,046, at 62,409 (8th Cir. 1986), which was not listed in any of these categories in the index. This case could have cited the guidelines in its discussion of whether the alleged behavior constituted RPM. Although it was sometimes a matter of judgment whether to count a particular case, we believe that the 97 decisions we counted represent a fair count of the relevant universe. 
In conclusion, the overall value of the Vertical Restraints Guidelines depends on their stated and unstated purposes. The guidelines successfully convey the Administration's inclination not to challenge vertical restraints in the absence of regulation or other governmentally imposed restrictions. The absence of any such challenges in the last several years reinforces the message. The guidelines also clearly express a respectable point of view and provide a general, all-purpose amicus curiae brief to the courts. They are least successful in two respects. They provide little guidance for the few investigations that reach the wide-ranging rule of reason analysis; a more structured Step Two approach, with clear presumptions of legality and illegality might have better limited all three types of error. The guidelines' summary of prevailing law also understates a firm's risk of facing a private suit or challenge by some state attorney general. The strength of the displeasure in Congress and among states' attorneys general and the poor reception by the courts suggest that a new Administration might revise or rescind the guidelines. Antitrust counselors must therefore advise their clients that they risk litigation if they rely on the guidelines as a statement of the law.

Since the guidelines appeared part way into volume 1985-1, we omitted decisions that appeared to have been written before the guidelines appeared. Since our LEXIS search of decisions that cited the guidelines included about half a year more than the $\mathrm{CCH}$ Trade Cases volumes that had been published by the time of our LEXIS search, our count understates the universe. For that reason, and because the indexes have apparently omitted some decisions that discuss vertical restraints, we feel confident that the true universe is at least 100 decisions that could have cited the guidelines.

88 One likely reason for the lack of deference to the guidelines is that vertical restraints cases have been almost entirely private in the last decade or so. In contrast, private parties other than targets of hostile takeover attempts must generally surmount numerous hurdles to obtain standing to challenge mergers. See, e.g., Cargill, Inc. v. Monfort of Colorado, Inc., 107 S. Ct. 484 (1986), A.B.A. Antitrust Section, AntItrust Law Developments 199-202 (2d ed. 1984); Susman, Standing in Private Antitrust Cases: Where Is the Supreme Court Going?, 52 ANTITRUST L.J. 465 (1983). As a result, the federal government brings a large majority of merger cases. The government thus has a larger claim for expertise in mergers than in vertical restraints. 